\title{
Outsourcing: Who Gains In The Short Run?
}

Giuliana Campanelli Andreopoulos, (E-mail: andreopoulosg@ wpunj.edu), William Paterson University Alexandros Panayides, (E-mail: panayidesa@wpunj.edu), William Paterson University

\begin{abstract}
Over the last several years there has been an intense debate over the issue of outsourcing. The two main topic questions of dispute are: What are the effects of outsourcing on employment and wages? What can be done to alleviate the cost of outsourcing on the labor side? In this paper we try to answer these two main questions. In particular, the scope of this paper is to understand the degree of substitutability between the domestic and the foreign labor due to outsourcing and its implications for both employment and reemployment. For this purpose, we will provide a rigorous definition of outsourcing and then illustrate a theoretical framework to analyze its effects.
\end{abstract}

\section{INTRODUCTION}

(๑) ver the last several years there has been an intense debate over the issue of outsourcing. This debate is not on the reasons for outsourcing (advances in technology, substantial investment in education in a number of developing countries together with low wages, innovation in business practice) but on who gains from outsourcing. There is no question that capital and shareholders are the winners, while domestic workers can be the losers even though it is not clear whether this happens in the long or short run. The effects of outsourcing on consumers are also controversial since fewer jobs and lower wages can outweigh the effect of cheaper prices on goods due to globalization. Finally contrasting views have been put forward on the possible scenarios for reemployment.

In this paper, we focus on the short-term effects of outsourcing, particularly on the labor side. The scope of the paper is to understand the degree of substitutability between the domestic and foreign labor due to outsourcing and its implication for both employment and reemployment. It is important to note that some type of skilled labor cannot be substituted such as jobs where face-to-face interaction plays an important role. Our model is confined to the kind of skilled labor that can be potentially substituted even though we will draw some conclusions on the labor complementarity too. It is worth noting that in our attempt to develop the theoretical model we have tried to be consistent with the empirical evidence.

The paper is organized as follows: Section two deals with the definition of outsourcing; section three illustrates the theoretical framework and discusses the implications of outsourcing for domestic employment and reemployment; and finally, section four provides concluding remarks.

\section{DEFINITION OF OUTSOURCING}

Most of the literature on outsourcing does not provide a rigorous definition of this phenomenon and is not clear whether or not it refers to trading in goods and/or services. When outsourcing refers to services only, most of the times the types of services it refers to are not specified. The usual definition of outsourcing is cross-border trade in services. However, WTO is more specific and categorizes four different ways in which services can be traded which are very well summarized in Bhagwati, et al. (2004). First, services are traded with the supplier and buyer remaining in their respective locations (for example x-rays from a hospital in New York can be read in Bangalore). Second, services are provided by moving the service recipient to the location of the service provider (for example tourism). Third, the service provider establishes a commercial presence in another country (for example banking and insurance). Fourth, the service seller moves to the location of the buyer (for example consulting services). ${ }^{1}$

\footnotetext{
${ }^{1}$ See Bhagwati, et al. (2004).
} 
For the purpose of this paper, we use the first type of definition, i.e., outsourcing refers to cross-border trade in services with the supplier and buyer remaining in their respective locations. This means that when we discuss the substitutability between domestic and foreign skilled labor we will assume no cost of transportation and custom inspection, unlike trade in goods.

\section{THE MODEL}

In the debate on outsourcing, there are two major positions about the substitutability of skilled labor in the short run. On the one side, are those who claim, that "the economy continues to hire the same endowment of domestic labor, but now paying the lower wage" Bhagwati, et al. (2004). On the other side, are those who suggest that the domestic labor is totally substituted by the foreign. In this section, we will use the competitive market for labor to clarify this controversy.

Consider the labor market for skilled labor. The demand can be represented as a negative function of real wages and coincides with the marginal product of labor. The supply is upward sloping showing a positive relationship between real wages and the quantity of labor supplied. Starting at the initial position A the economy is employing $0 \mathrm{~L}_{1}$ quantity of labor at $0 \mathrm{~W}_{1}$ wages (figure 1 ). Lets now assume that because of lower wages $0 \mathrm{~W}_{2}$ the economy decides to outsource some of its labor, which then implies an increase in employment $0 \mathrm{~L}_{2}$ (point $\mathrm{B}$ in figure 1 ). In order to discuss the effects from outsourcing we need to understand the changes in composition of the labor force and wages.

There are four cases to be examined:

\section{Case 1 (Partial Substitution)}

Let's assume that position A in figure 1 represents the equilibrium in the labor market with no international trade. Position B shows that opening to international trade creates a shortage in the labor market represented by the segment $\mathrm{L}_{0} \mathrm{~L}_{2}$. This shortage is totally filled with foreign labor. This means that there is a substitution effect $\mathrm{L}_{0} \mathrm{~L}_{1}$ since the domestic labor is now replaced with the foreign labor. $0 \mathrm{~L}_{0}$ is the amount of the domestic labor force, which remains at the outsourcing wage.

Needless to say, we are assuming here that if B is the new equilibrium there will be a shift in the supply of labor due to the foreign country effect. In addition, if the demand for labor is a derived demand from the product market, then point $\mathrm{B}$ is associated with higher production and income.

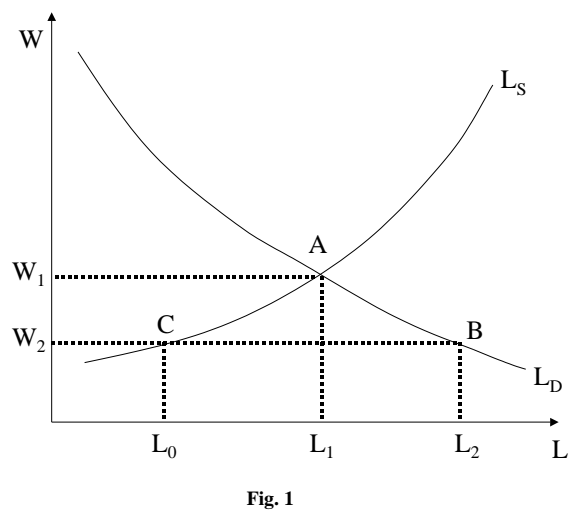

It is not easy to reconcile this model with what happens in the real world since wages in the United States are much higher than in the outsourcing countries. For example, in the United States the average salary for programmers in 2004 was $\$ 65,000$ while in India, one of the leading countries in outsourcing for programmers, was $\$ 7,500$ and in 
China $\$ 7,550$. This means that the average wage in the United States is approximately nine times the one paid in the outsourcing countries (see table 1).

Table 1: Salary Gap - Average Salary for Programmers

\begin{tabular}{|l|c|c|c|}
\hline Country & Salary & Country & Salary \\
\hline Brazil & $\$ 12,500$ & Mexico & $\$ 20,500$ \\
\hline Canada & 37,500 & Philippines & 8,700 \\
\hline China & 7,550 & Poland & 8,100 \\
\hline Czech. Rep. & 12,350 & Romania & 7,700 \\
\hline Hungary & 10,500 & Russia & 10,000 \\
\hline India & 7,500 & Singapore & 30,950 \\
\hline Ireland & 24,500 & South Africa & 18,000 \\
\hline Israel & 29,150 & U.S. & 65,000 \\
\hline Malaysia & 10,750 & Vietnam & 3,475 \\
\hline
\end{tabular}

Source: NeoIT. Inc., San Ramon, Calif.

Additional data on wages in U.S. and India show that the divergence in wages between the two countries is not confined to programmers, but is extended to many other occupations. In some cases, like Telephone Operators, Payroll Clerks, etc., US wages are 12 times as high (see table 2).

Table 2: Hourly Wages for Selected Occupations, U.S. and India, 2002-2003

\begin{tabular}{|l|c|c|}
\hline Occupation & US & India \\
\hline Telephone Operator & $\$ 12.57$ & Under $\$ 1.00$ \\
\hline Health Record Technologist & 13.17 & $1.50-2.00$ \\
\hline Payroll Clerk & 15.17 & $1.50-2.00$ \\
\hline Legal Assistant/Paralegal & 17.86 & $6.00-8.00$ \\
\hline Accountant & 23.35 & $6.00-15.00$ \\
\hline Financial Researcher/Analyst & $33.00-35.00$ & $6.00-15.00$ \\
\hline
\end{tabular}

Source: Ashok Deo Bardhan and Cynthia Kroll, “The New Wave of Outsourcing” (2003).

\section{Case 2 (Complete Substitution)}

The empirical evidence supports the idea of a domestic supply of labor well above the outsourcing wages. This, in turn, implies that the after trade employment is totally composed of outsourced workers $0 \mathrm{~L}_{2}$ and the substitution of domestic labor is now complete (see figure 2).

Up to now, we have shown two possible effects of the outsourcing: a partial and a complete substitution, but in no case the economy is able to keep the same amount of domestic labor at the outsourcing level of wages. 


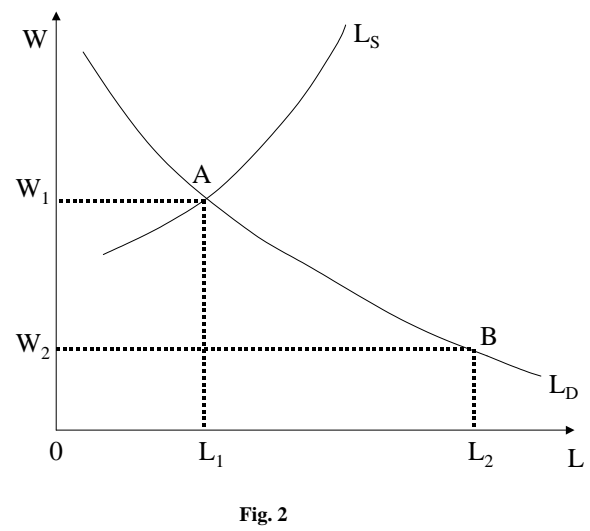

The next problem is the reemployment. Once again, here we have contrasting views. Some believe that a reduction in wages is the key element for employment growth, while some others stress the crucial role of increases in profits. Let's examine them separately.

\section{Case 3 (Supply Side Reemployment)}

It might be that the pressure of outsourcing and the consequent unemployment will reduce domestic wages. If this is the case, then the effect on outsourcing will be a shift in the domestic supply of labor to the right, as figure 3 shows. In particular, if the reduction in domestic wages is substantial, then some of the domestic labor will be reemployed $\left(0 \mathrm{~L}_{0}\right.$ in figure 3). Empirical research, Kletzer (2002), does not support the case of a substantial reduction in domestic wages, which means that this particular form of reemployment is not very feasible for the time being. According to Kletzer, on average those reemployed earned ten percent less than before.

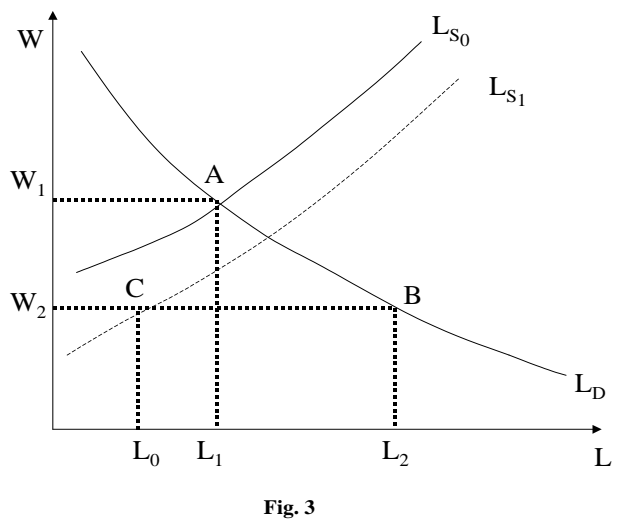

\section{Case 4 (Demand Side Reemployment)}

Some authors, Karmin (2004) and Schroeder (2004) believe that outsourcing has positive effects in the short run. The main idea is that the use of service labor abroad reduces labor costs, leads to greater productivity and profits for US firms which can, in turn, finance new investment and create new jobs. One US industry-sponsored study estimated that 90,264 jobs were created in the United States in 2003 because of this scenario and in 2008, 317,367 will be created (see table 3). Actually the study claims that twice the number of US jobs is created than displaced, producing wage increases in various sectors. 
In addition, demand for US exports is expected to increase due to the relatively lower price of US produced goods and services and higher incomes in the outsourcing countries. It has been estimated an increase in exports of 2.3 billion US dollars in 2003 and it is expected to increase to 9 billion in 2008. In addition, higher incomes in the outsourcing companies have produce higher demand for US workers. For example, Infosys Technologies in Bangalore has become so profitable because of outsourcing that in 2004 planned to set up a consulting operation in the US using US consultants (approximately 20 million investment to create nearly 500 jobs), Srinivasan (2004).

Table 3: Estimated new U.S. jobs created from outsourcing abroad, according to an industry study

\begin{tabular}{|l|c|c|}
\hline & $\mathbf{2 0 0 3}$ & $\mathbf{2 0 0 4}$ \\
\hline Natural Resources \& Mining & 1,046 & 1,182 \\
\hline Construction & 19,815 & 75,757 \\
\hline Manufacturing & 3,078 & 25,010 \\
\hline Wholesale Trade & 20,456 & 43,359 \\
\hline Retail Trade & 12,552 & 30,931 \\
\hline Transportation \& Utilities & 18,895 & 63,513 \\
\hline Publishing, Software \&Communications & 24,860 & $-50,043$ \\
\hline Financial Services & 5,604 & 32,066 \\
\hline Professional \& Business Services & 14,667 & 31,623 \\
\hline Education \& Health Services & 18,015 & 47,260 \\
\hline Leisure, Hospitality \& Other Services & 4,389 & 12,506 \\
\hline Government & $-3,393$ & 4,203 \\
\hline Total Employment & $\mathbf{9 0 , 2 6 4}$ & $\mathbf{3 1 7 , 3 6 7}$ \\
\hline
\end{tabular}

Source: Global Insight and North American Industry Classification System

Needless to say, this is quite a different scenario from case 3 since here the reemployment will be due to a shift in the demand for labor, which will produce an increase in employment and wages. However, it is important to note that this increase in employment is in a complementary market. For example, Karmin reports the case of a firm in New Jersey that sent work abroad to Bombay to file insurance claims on behalf of NJ doctors. This procedure reduced costs so much that the firm obtained a sizable number of new customers and now is expanding its operations in the United States. In particular, the firm added a sales team for recruiting clients and hired new managers in the US to work with doctors.

Thus, the complementarily factor makes the reemployment prospects less pessimistic, moreover other factors should be considered, in particular, the small number and types of outsourced jobs. It has been estimated that the total number of outsourced jobs averages less than 300,000 per year, Samuelson, R (2004). That amounts to only 0.002 of all U.S. jobs. In addition, as already mentioned, not all service jobs can be outsourced. In the United States about seventy percent of jobs are in services such as retailing, catering, restaurants and hotels, tourism and personal care and since they require face-to-face relationship between producers and consumers can not be easily substituted.

\section{CONCLUSION}

In this paper, we tried to understand the effects of outsourcing on the labor market in the short run. Considering first the effects of outsourcing on domestic employment, two are the possible outcomes. First, outsourcing will produce a partial substitution of the domestic labor force. Second, and more realistic, there will be a total substitution of the domestic labor force with foreign workers. There is no reason to expect the same quantity of employment at the outsourcing level of wages 
Coming to reemployment, two are the possible scenarios. First, supply side reemployment is possible only if there is a substantial reduction in wages, which once again does not appear to be a practical alternative. Second, the demand side reemployment, according to which outsourcing will have positive effect on the domestic demand for labor via reduction in costs and increase in profits and exports. The crucial aspect for this result is the complementarity between factors of production and face-to-face relationship, which seems to play a crucial role in the reemployment process. If the complementarity effect is greater than the substitutability effect, then not only capital but also labor gains.

For those who are skeptical about the demand side reemployment effect, a possible solution is a government intervention whose scope is to retraining the job losers so that they can move to that segment of the skilled labor force for which there is no substitution. Protectionism is not an alternative.

\section{REFERENCES}

1. Bhagwati, J., Panagariya, A., and Srinivasan, T. N. (2004). The Muddles over Outsourcing. Journal of Economic Perspectives, 18 (4), 93-115.

2. Davis, B. (2004). Some Democratic Economists Echo Mankiw on Outsourcing. The Wall Street Journal, February 12, A2.

3. Karmin, C. (2004). Offshoring Can Generate Jobs in the U.S. The Wall Street Journal, March 16, B1.

4. Kletzer, L. (2002). Imports, Exports, and Jobs: What does trade mean for employment and job loss? W.E. Upjohn Institute of Employment Research, December.

5. Samuelson. P. (2004). Where Ricardo and Mill Rebut and Confirm Arguments of Mainstream Economists Supporting Globalization. Journal of Economic Perspectives, 18 (3), 135-147.

6. Samuelson, R. (2004). Threat of Outsourcing Overstated. The Charlotte Observer, January 17, 13A.

7. Schroeder, M. (2004). Outsourcing May Create U.S. Jobs. The Wall Street Journal, March 30, A2.

8. Srinivasan, R. (2004). Outsource Magnet to Hire in U.S. The Charlotte Observer, April 9, 3D. 